\title{
Spouses' Psychological States and Family Relations in Families with Natural and Induced Pregnancies
}

\author{
Tatiana G. Bokhan ${ }^{a \star}$, Olga V. Terekhina ${ }^{a}$, Marina V. Shabalovskaya ${ }^{a, b}$, \\ Svetlana B. Leshchinskaia ${ }^{a}$, Anna V. Silaeva ${ }^{a, b}$, Elena A. Naku ${ }^{a}$, \\ Fatos Selita ${ }^{\mathrm{a}, \mathrm{c}}$, Lyubov A. Agarkova ${ }^{\mathrm{d}}$ \\ a National Research Tomsk State University, Tomsk, Russia, \\ b Siberian State Medical University, Tomsk, Russia \\ c Department of Psychology, Goldsmiths, University of London, United Kingdom \\ ${ }^{\mathrm{d}}$ Research Institute of Obstetrics, Gynecology and Perinatology, Tomsk National Research Medi- \\ cal Center of the Russian Academy of Sciences, Tomsk, Russia \\ *Corresponding author. E-mail: btg960@mail.ru
}

Background. Psychological tension in the family, along with stress and mental and physical illness, are linked to the reproductive health of parents, as well as to the outcomes of infertility treatments and pregnancy overall.

Objective. To compare stress and negative affect (depression, irritability, and anxiety) in families with induced pregnancies (in-vitro fertilization, IFV) vs. natural pregnancies. The relationship between negative affect and stress in pregnant women was explored in both groups. Finally, the study investigated links between negative affect and partner relationships.

Design. The sample included 308 women and 278 men from couples with natural conception, and 131 women and 102 men from couples with an IVF pregnancy.

Results. Relatively low levels of negative affective states and stress were found in families with both natural and induced pregnancies. Moderate correlations were found between women's negative affect and their stress level in both groups. Significant correlations were found in both groups between negative psychological states of the spouses, as well as between negative psychological states and warmth/hostility in marital relations.

Conclusion. The results suggest that psychological states, stress levels, and links between psychological states and quality of family relations are similar in families with IVF and those with natural pregnancies. Further longitudinal research is needed to explore the direction of causal links between the psychological states of the spouses, and between their psychological states and the quality of family relations.

Keywords: pregnancy, IVF, infertility, family relationships, stress, psychological states 


\section{Introduction}

Psychological states of spouses may influence communication and the quality of the relationship between them. In turn, the quality of spousal relations may influence their psychological states (Kouros, Papp, \& Cummings, 2008; Vujeva \& Furman, 2011). Psychological tension in the family, along with stress and mental and physical illness, have been shown to affect the reproductive health of the parents, as well as the outcomes of infertility treatments and pregnancy overall (Ebbesen et al., 2009; Fadeeva, Vostrikov, \& Garganeeva, 2011; Frederiksen, Farver-Vestergaard, Skovgård, Ingerslev, \& Zachariae, 2015; Galhardo, Cunha, \& Pinto-Gouveia, 2011).

\section{Psychological States of Spouses during IVF Treatment}

A number of studies have investigated the psychological states of spouses while undergoing in-vitro fertilization (IVF) treatment, as well as during the pregnancy (Feklicheva et al., 2017; Greil, Shreffler, Schmidt, \& McQuillan, 2011; Klemetti, Raitanen, Sihvo, Saarni, \& Koponen, 2010; Naku et al. 2016; Petrova, Podolhov, Gzgzyan, \& Ngauri, 2013; Purewal, Chapman, \& Van Den Akker, 2017). Research suggests that diagnosed infertility can be almost as stressful as the loss of a relative, incurable disease, divorce, and other extremely traumatic events (Naku, Kovas, Bohan, Terehina, \&Vidyakina, 2017). In some people, in-vitro fertilization can lead to an inferiority complex, psychological suffering, and anxiety (Wichman, Ehlers, Wichman, Weaver, \& Coddington, 2011; Lin \& Chueh, 2016). Such psychological problems may occur when it is impossible to conceive a child naturally and after unsuccessful IVF attempts (Filippova, 2009; Hynes, Callan, Terry, \& Gallois, 2011). One or both partners (spouses) may have a depressed mood, decreased energy, and low general well-being (Haimovici et al., 2018; Maroufizadeh, Karimi, Vesali, \& Omani Samani, 2015; Pasch et al., 2016; Williams, Marsh, \& Rasgon, 2007). Negative emotions of people suffering from infertility can also be accompanied by negative self-perception, a negative and inconsistent self-image, and self-blame, which can negatively affect family life satisfaction (Filippova, 2009; Greil, SlausonBlevins, \& McQuillan, 2010).

Studies of anxiety among pregnant women and their partners participating in an IVF treatment have produced inconsistent results (Gourounti et al., 2012; Hjelmsted, Widström, Wramsby, \& Collins, 2003; Klock \& Greenfeld, 2000). One study showed that women and men undergoing IVF had a higher level of anxiety about losing the pregnancy than people with natural conception (Hjelmsted, Widström, Wramsby, Matthiesen, \& Collins, 2003). However, another prospective longitudinal study found that the women conceiving through IVF (but not the naturally conceiving women) had on average decreased anxiety and increased self-esteem during pregnancy (Klock \& Greenfeld, 2000). Another study found that fertility-related stress and state anxiety positively correlated with avoidance coping and low perception of personal control in women undergoing IVF (Gourounti et al., 2012).

Apart from anxiety, other negative affective states have also been found in women undergoing IVF (Petrova et al., 2013; Seok Kee, Jung, \& Lee, 2000; Sbaragli et al., 2008; Zaharova \& Yakupova, 2015). For example, one study showed that 
more women in this group tended to ignore actual and potential problems, to idealize pregnancy and motherhood, and to have euphoric and unrealistic ideas about their future child and about themselves (Zaharova \& Yakupova, 2015).

\section{Family Relations}

Much research has found a link between marital conflicts and psychological disorders (Choi \& Marks, 2008; Du Rocher Schudlich, Papp, \& Cummings, 2011; Kouros \& Cummings, 2011; Pellerone \& Miccichè, 2014). Lack of mutual understanding in the family may lead to depression, estrangement, a decline in psychological and physical health, and a decrease in the partners' ability to work. Specifically, for families engaged in the IVF procedure, spousal relationships may face serious challenges at all stages: decision making, participation in the IVF program, period of pregnancy, childbirth, and child development (Greil et al., 2010). Special circumstances associated with IVF, such as diagnosed infertility (both male and female), unsuccessful conception attempts, and a complicated pregnancy, can have a negative impact on the psychological state of the partners and their family relationships, and may undermine the development of parental identity (Faria, Grieco, \& Barros, 2012).

To sum up, research suggests that induced pregnancy, such as through IVF, is accompanied by higher levels of anxiety and other negative affective states, strained family relations, and increased risk of miscarriage (Massey et al., 2016). In addition, it is often preceded by unsuccessful IVF attempts, which may also lead to elevated stress. Therefore, IVF pregnancy is considered to be more stressful, on average, than natural pregnancy. However, some studies did not find differences between families with naturally conceived and induced pregnancies. Moreover, to date limited research is available on the association between family relationships and psychological states of partners in families who undergo IVF, compared to families with natural pregnancy.

\section{Methods}

\section{Hypotheses}

The present study compared affective states in families with induced and natural pregnancies, and explored the association between negative affect and marital relations. Based on previous research, the following five hypotheses were formulated:

1. Families with induced pregnancy will on average experience greater stress and negative affective states than families with natural pregnancies.

2. Negative affect will be correlated with women's stress during the pregnancy.

3. Negative affect will be associated with more problematic marital relations in both types of families.

4. Psychological states of spouses will be modestly correlated-i.e., the partners, on average, will show some similarity in their psychological states.

5. There will be a modest to moderate correlation between warmth or hostility that partners report towards their partners and what their partners perceive about them. 


\section{Participants}

Participants were part of the Prospective Longitudinal Interdisciplinary Study (PLIS) conducted in Russia (see Voronina, Bohan, Terehina, Malykh, \& Kovas, 2016, for details). The study was approved by the Ethics Committee for Interdisciplinary Investigations, Tomsk State University. All participants provided written informed consent. The sample included 439 women and 380 men: 308 women and 278 men were from couples with natural conception, and 131 women and 102 men with an IVF pregnancy. All participants were recruited from four family-planning clinics in three cities of Russia's Siberian Federal Districts.

\section{Measures}

Men completed a Questionnaire for the Father and women completed a Questionnaire for the Mother during the first and third trimesters of pregnancy.

1. Irritability, Depression and Anxiety scale (IDA; Snaith, Constantopoulos, Jardine, \& McGuffin, 1978). The IDA, translated and adapted for use in Russian, contains 18 statements, such as "I feel cheerful", "I feel I might lose control and hit or hurt someone", and "I get angry with myself or call myself names". Responses to the statements are measured on a 4-point Likert scale, ranging from 0 (No, not at all) to 3 (Yes, definitely). The questionnaire measures the intensity of depression, outward irritability, inward irritability, and anxiety. For each scale there is a cut-off point, with exceeding values indicating the presence of depression (4-6 points), anxiety (6-8 points), outward irritability (5-7 points), and inward irritability (4-6 points).

2. Emotional State during Pregnancy Scale (Rice et al. 2010). This single-item measure, translated and adapted for use in Russian, was completed only by women. The woman indicates on an 11-point Likert scale (from 0 to 10) how stressed and worried she feels (10 means "calm and relaxed", 0 means "stressed and worried"). The data were collected twice, evaluating three different periods of the pregnancy: in the first trimester, women reported about the first 12 weeks of pregnancy; in the third trimester, they responded about the period from 13 to 25 weeks and the period from the 26th week of pregnancy. Values from 0 to 3 indicate high stress, from 4 to 7 - medium (optimum), and from 8 to $10-$ low.

3. Iowa Family Interaction Rating Scales (Melby et al., 1998). The measure includes nine items, each assessed on a 7-point Likert scale (1-never, 7-always). Each spouse assessed their own emotional warmth (five questions) and hostility (five questions) towards the partner, as well as the perceived warmth and hostility of the partner towards them. The warmth of the relationship was calculated as the mean score of: (a) the woman's warmth towards her partner, (b) the woman's perceived warmth of her partner towards her, (c) the man's warmth towards his partner, and (d)) the man's perceived warmth of his partner towards him. Hostility was calculated as the mean score of (a) the woman's hostility towards her partner, (b) the woman's perceived hostility of her partner towards her, (c) the man's hostility towards his partner, and (d) the man's perceived hostility of his partner towards him.

The overall index of the relationships was also estimated. Higher values on the warmth scale indicated warmer relationships; higher values on the hostility scale indicated greater hostility. The hostility scale was reversed, so that lower values indicated greater hostility. The overall index was calculated as the sum of the two 
scales, so that low values indicated problems in family interactions and high values indicated good relationships.

The statistical analysis was performed with the IBM SPSS Statistics Version 23.0 software package. The following analyses were performed to test the hypotheses: descriptive statistics, Spearman's rank correlation, the Mann-Whitney U test, and correlation comparisons using Fisher-Z-Transformation.

\section{Results}

\section{Negative Affective States of Pregnant Women}

The Irritability, Depression and Anxiety scale was used to measure negative affective states. The mean scores of all parameters in both groups lie within the normal range (see Table 1 ).

Table 1

Descriptive statistics, Irritability, Depression and Anxiety scale (pregnant women)

\begin{tabular}{|c|c|c|c|c|c|c|c|c|}
\hline & \multicolumn{2}{|c|}{$\begin{array}{l}\text { Depression } \\
(0-15 \text { points })\end{array}$} & \multicolumn{2}{|c|}{$\begin{array}{c}\text { Outward } \\
\text { Irritability } \\
(0-12 \text { points })\end{array}$} & \multicolumn{2}{|c|}{$\begin{array}{c}\text { Inward } \\
\text { Irritability } \\
(0-12 \text { points })\end{array}$} & \multicolumn{2}{|c|}{$\begin{array}{c}\text { Anxiety } \\
(0-15 \text { points })\end{array}$} \\
\hline & Natural & IVF & Natural & IVF & Natural & IVF & Natural & IVF \\
\hline $\mathrm{N}$ & 278 & 102 & 278 & 102 & 278 & 102 & 278 & 102 \\
\hline Mean & 3.14 & 3.26 & 3.43 & 2.93 & 1.18 & 1.00 & 5.51 & 5.50 \\
\hline Median & 3.00 & 3.00 & 3.00 & 2.50 & 1.00 & 1.00 & 5.00 & 5.00 \\
\hline Mode & 2.00 & 3.00 & 1.00 & 2.00 & 0.00 & 0.00 & 6.00 & 4.00 \\
\hline Std. Deviation & 2.15 & 2.14 & 2.19 & 2.03 & 1.26 & 1.16 & 2.88 & 2.88 \\
\hline Dispersion & 4.63 & 4.59 & 4.84 & 4.12 & 1.60 & 1.34 & 8.29 & 8.27 \\
\hline $\begin{array}{l}\% \text { of women with } \\
\text { elevated levels }\end{array}$ & 6.4 & 3.9 & 4.7 & 2.3 & 0.3 & 0 & 14.9 & 12.2 \\
\hline $\begin{array}{l}\text { Mann-Whitney } \\
\text { U test }\end{array}$ & \multicolumn{2}{|c|}{$13,481.5$} & \multicolumn{2}{|c|}{12,448} & \multicolumn{2}{|c|}{13,100} & \multicolumn{2}{|c|}{14,205} \\
\hline $\mathrm{p}$ & \multicolumn{2}{|c|}{0.55} & \multicolumn{2}{|c|}{0.05} & \multicolumn{2}{|c|}{0.21} & \multicolumn{2}{|c|}{0.98} \\
\hline
\end{tabular}

An increased level of negative psychological states was observed in some women in both groups. High levels of depression ( $>6$ points) were observed in $6.4 \%$ of women with natural conception and 3.9\% of women with IVF. High levels of outward irritability ( $>7$ points) were observed in $4.7 \%$ of women with natural conception and $2.3 \%$ of women with IVF. High levels of inward irritability (> 6 points) were observed in $0.3 \%$ of women with natural conception and none of the women with IVF. High levels of anxiety ( $>8$ points) were observed in $14.9 \%$ of women with natural conception and $12.2 \%$ of women with IVF.

The Mann-Whitney $\mathrm{U}$ test revealed significant differences in outward irritability between the two groups, with significantly higher levels in women with natural pregnancy than women with induced pregnancy. 


\section{Stress of Women during Pregnancy}

As shown in Table 2, the mean scores of women's stress level in both groups (induced vs. natural pregnancy) during all three trimesters were in the normal range (4-7 points). Mean scores for stress in both groups during the third trimester were lower than in the first and second trimesters, but the difference was not significant.

Table 2

Descriptive statistics for stress during pregnancy

\begin{tabular}{|c|c|c|c|c|c|c|}
\hline & \multicolumn{6}{|c|}{ Stress } \\
\hline & \multicolumn{2}{|c|}{ 0-12 weeks } & \multicolumn{2}{|c|}{ 13-25 weeks } & \multicolumn{2}{|c|}{ from 26 weeks } \\
\hline & Natural & IVF & Natural & IVF & Natural & IVF \\
\hline $\mathrm{N}$ & 295 & 122 & 280 & 105 & 272 & 98 \\
\hline Mean & 6.74 & 6.47 & 6.90 & 6.70 & 7.16 & 7.19 \\
\hline Median & 7.00 & 6.00 & 7.00 & 7.00 & 8.00 & 7.00 \\
\hline Mode & 8 & 6 & 8 & 8 & 8 & 6 \\
\hline Std. Deviation & 2.27 & 2.09 & 2.16 & 2.59 & 1.94 & 1.94 \\
\hline Dispersion & 5.16 & 4.38 & 4.66 & 6.71 & 3.76 & 3.75 \\
\hline $\begin{array}{l}\% \text { of women with 'at risk' } \\
\text { stress level }(0-3)\end{array}$ & 7.5 & 7.4 & 6.1 & 12.4 & 4 & 3.1 \\
\hline Mann-Whitney U test & \multicolumn{2}{|c|}{$16,472.5$} & \multicolumn{2}{|c|}{14,409} & \multicolumn{2}{|c|}{13,250} \\
\hline $\mathrm{p}$ & \multicolumn{2}{|c|}{0.17} & \multicolumn{2}{|c|}{0.76} & \multicolumn{2}{|c|}{0.93} \\
\hline
\end{tabular}

In each trimester, women scoring below 3 points were identified as an at-risk group for developing mental health problems, potentially having an unfavorable influence on the pregnancy and the postpartum period. In the IVF group, increased stress was observed in $7.4 \%$ of women in the first trimester, $12.4 \%$ in the second trimester, and $3.1 \%$ in the third trimester. In the natural conception group, increased stress was observed in $7.5 \%$ of women in the first trimester, $6.1 \%$ in the second trimester, and $4 \%$ in the third trimester. The Mann-Whitney $\mathrm{U}$ test did not show significant differences between women with natural and induced pregnancy.

Association Between Negative Affect and Stress in Pregnant Women

Spearman's rank correlation was used to assess the relationship between negative affect and the stress of pregnant women (see Table 3). In the natural conception group, significant modest to moderate negative correlations were observed between all psychological states and stress level in all trimesters. Negative correlations indicate that higher stress is associated with worse psychological states (the stress level scale is reversed, with low scores corresponding to high stress). The highest correlation was found between stress in the third trimester and depression $(\mathrm{r}=-0.51 ; \mathrm{p}=0.00)$ and anxiety $(\mathrm{r}=-0.58 ; \mathrm{p}=0.00)$, suggesting that women who experienced greater stress also experienced significantly more negative affect.

In the IVF group, significant correlations were observed between depression and stress in all trimesters of pregnancy, between outward irritability and stress in 
the first and second trimesters, and between anxiety and stress in the second and third trimesters. The highest correlation was found between depression and stress in the second trimester $(\mathrm{r}=-0.56 ; \mathrm{p}=0.00)$.

Fisher $\mathrm{Z}$ was used to test whether the observed correlations between negative affect and stress differed significantly between the IVF and natural pregnancy groups of women. The results showed that correlation between stress in the first trimester and inward irritability was greater in the natural conception group. Correlation between stress in the second trimester and depression was significantly greater in women with an IVF pregnancy than in the natural conception group. In the third trimester, correlations between stress and anxiety, stress and outward irritability, and stress and inward irritability were greater in the natural conception group than in the IVF group.

Table 3

Relationship between negative psychological states of pregnant women and their stress level

\begin{tabular}{|c|c|c|c|c|c|c|c|c|c|c|}
\hline & & \multicolumn{9}{|c|}{ Stress } \\
\hline & & \multicolumn{3}{|c|}{ first trimester } & \multicolumn{3}{|c|}{ second trimester } & \multicolumn{3}{|c|}{ third trimester } \\
\hline & & 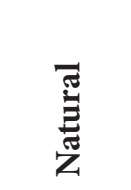 & $\sum$ & 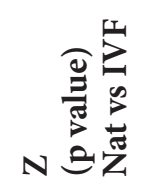 & 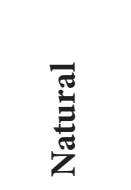 & $\sum^{1}$ & 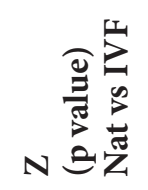 & 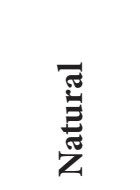 & $\sum$ & 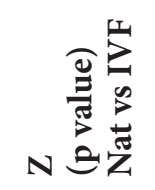 \\
\hline \multirow{3}{*}{ 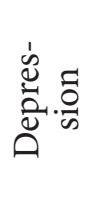 } & $\mathrm{r}$ & $-0.18^{* *}$ & $-0.25^{*}$ & & $-0.31^{* *}$ & $-0.56^{* *}$ & & $-0.51^{* *}$ & $-0.42^{* *}$ & \\
\hline & $\mathrm{p}$ & 0.00 & 0.01 & $\begin{array}{c}0.61 \\
(p=0.27)\end{array}$ & 0.00 & 0.00 & $\begin{array}{c}2.64 \\
(p=0.00)\end{array}$ & 0.00 & 0.00 & $\begin{array}{c}-0.94 \\
(p=0.17)\end{array}$ \\
\hline & $\mathrm{N}$ & 268 & 95 & & 274 & 100 & & 268 & 93 & \\
\hline \multirow{3}{*}{ 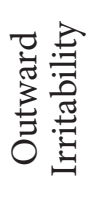 } & $\mathrm{r}$ & $-0.13^{*}$ & $-0.22^{*}$ & & $-0.23^{\star *}$ & $-0.24^{*}$ & & $-0.29^{* *}$ & -0.02 & \\
\hline & $\mathrm{p}$ & 0.03 & 0.03 & $\begin{array}{c}0.77 \\
(p=0.22)\end{array}$ & 0.00 & 0.01 & $\begin{array}{c}0.09 \\
(p=0.46)\end{array}$ & 0.00 & 0.86 & $\begin{array}{c}-2.30 \\
(p=0.01)\end{array}$ \\
\hline & $\mathrm{N}$ & 270 & 96 & & 277 & 101 & & 271 & 94 & \\
\hline \multirow{3}{*}{ 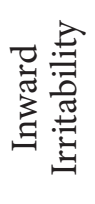 } & $\mathrm{r}$ & $-0.26^{* *}$ & 0.13 & & $-0.19^{* *}$ & -0.06 & & $-0.27^{* *}$ & -0.04 & \\
\hline & $\mathrm{p}$ & 0.00 & 0.19 & $\begin{array}{c}-3.29 \\
(p=0.00)\end{array}$ & 0.00 & 0.54 & $\begin{array}{c}-1.12 \\
(\mathrm{p}=0.13)\end{array}$ & 0.00 & 0.71 & $\begin{array}{c}-1.95 \\
(p=0.03)\end{array}$ \\
\hline & $\mathrm{N}$ & 269 & 96 & & 275 & 101 & & 269 & 94 & \\
\hline \multirow{3}{*}{ 竞 } & $\mathrm{r}$ & $-0.27^{* *}$ & -0.17 & & $-0.34^{* *}$ & $-0.40^{* *}$ & & $-0.58^{* *}$ & $-0.35^{* *}$ & \\
\hline & $\mathrm{p}$ & 0.00 & 0.10 & $\begin{array}{c}-0.87 \\
(p=0.19)\end{array}$ & 0.00 & 0.00 & $\begin{array}{c}0.59 \\
(p=0.28)\end{array}$ & 0.00 & 0.00 & $\begin{array}{c}-2.45 \\
(p=0.01)\end{array}$ \\
\hline & $\mathrm{N}$ & 269 & 96 & & 276 & 101 & & 270 & 94 & \\
\hline
\end{tabular}

Note. ${ }^{*}$ Correlation significant at $p=0.01$. ${ }^{*}$ Correlation significant at $p=0.05$. Lower scores for stress indicate greater stress; therefore, the negative sign of the associations indicates positive associations between stress and negative affect (more stress is associated with more negative affect). $Z=$ Fisher $Z$, comparison between IVF and natural pregnancy groups. The sign of $Z$ can be ignored, with significance level indicating whether the stronger correlation (positive or negative) is significantly stronger. 


\section{Negative Psychological States of Partners of Pregnant Women}

The mean scores of women's partners' psychological states were overall similar to the women's scores, and were also in the normal range (see Table 4). The MannWhitney $U$ test showed that the differences between the two groups were not significant.

Table 4

Descriptive statistics, Irritability, Depression and Anxiety scale (men)

\begin{tabular}{|c|c|c|c|c|c|c|c|c|}
\hline & \multicolumn{2}{|c|}{ Depression } & \multicolumn{2}{|c|}{$\begin{array}{l}\text { Outward } \\
\text { Irritability }\end{array}$} & \multicolumn{2}{|c|}{$\begin{array}{c}\text { Inward } \\
\text { Irritability }\end{array}$} & \multicolumn{2}{|c|}{ Anxiety } \\
\hline & Natural & IVF & Natural & IVF & Natural & IVF & Natural & IVF \\
\hline $\mathrm{N}$ & 278 & 102 & 278 & 102 & 278 & 102 & 278 & 102 \\
\hline Mean & 3.05 & 3.08 & 3.15 & 3.10 & 1.47 & 1.24 & 4.43 & 4.36 \\
\hline Median & 3.00 & 3.00 & 3.00 & 3.00 & 1.00 & 1.00 & 4.00 & 4.00 \\
\hline Mode & 3.00 & 4.00 & 3.00 & 1.00 & 0.00 & 0.00 & 3.00 & 4.00 \\
\hline Std. Deviation & 2.01 & 1.78 & 2.30 & 2.38 & 1.53 & 1.30 & 2.64 & 2.40 \\
\hline Dispersion & 4.03 & 3.16 & 5.30 & 5.65 & 2.36 & 1.70 & 6.97 & 5.76 \\
\hline $\begin{array}{l}\% \text { of men with } \\
\text { elevated levels }\end{array}$ & 4.8 & 2.3 & 3.5 & 3.9 & 0.9 & 0 & 5.8 & 3.8 \\
\hline $\begin{array}{l}\text { Mann-Whitney } \\
\text { U test }\end{array}$ & \multicolumn{2}{|c|}{12,166} & \multicolumn{2}{|c|}{12,491} & \multicolumn{2}{|c|}{$11,858.5$} & \multicolumn{2}{|c|}{$12,254.5$} \\
\hline $\mathrm{p}$ & \multicolumn{2}{|c|}{0.61} & \multicolumn{2}{|c|}{0.78} & \multicolumn{2}{|c|}{0.28} & \multicolumn{2}{|c|}{0.81} \\
\hline
\end{tabular}

\section{Relationship Between Negative Psychological States of Spouses and Quality of Marital Relations}

Descriptive statistics for men's and women's experienced and perceived warmth and hostility are presented in Tables 5 and 6.

Table 5

Descriptive statistics of warmth (Iowa scale)

\begin{tabular}{lcccccccc}
\hline & \multicolumn{2}{c}{$\begin{array}{c}\text { Women's } \\
\text { warmth }\end{array}$} & \multicolumn{2}{c}{$\begin{array}{c}\text { Women's } \\
\text { perceived warmth }\end{array}$} & \multicolumn{2}{c}{$\begin{array}{c}\text { Men's } \\
\text { warmth }\end{array}$} & \multicolumn{2}{c}{$\begin{array}{c}\text { Men's perceived } \\
\text { warmth }\end{array}$} \\
\cline { 2 - 10 } & Nat. & IVF & Nat. & IVF & Nat. & IVF & Nat. & IVF \\
\hline N & 277 & 101 & 274 & 100 & 277 & 92 & 280 & 92 \\
Mean & 27 & 28.3 & 27.2 & 286 & 27.4 & 29 & 27.7 & 29.4 \\
Median & 29 & 29 & 30 & 30,5 & 29 & 30 & 30 & 31 \\
Mode & 35 & 35 & 35 & 35 & 35 & 35 & 35 & 35 \\
Std. Deviation & 6.8 & 5.5 & 7.6 & 6.4 & 6.9 & 5.6 & 7.5 & 6.7 \\
Dispersion & 46.3 & 30.8 & 58.4 & 41.1 & 48.3 & 31 & 55.9 & 44.8 \\
\hline
\end{tabular}


Table 6

Descriptive statistics of hostility (Iowa scale)

\begin{tabular}{lcccccccc}
\hline & \multicolumn{2}{c}{$\begin{array}{c}\text { Women's } \\
\text { hostility }\end{array}$} & \multicolumn{2}{c}{$\begin{array}{c}\text { Women's } \\
\text { perceived hostility }\end{array}$} & \multicolumn{2}{c}{$\begin{array}{c}\text { Men's } \\
\text { hostility }\end{array}$} & \multicolumn{2}{c}{$\begin{array}{c}\text { Men's perceived } \\
\text { hostility }\end{array}$} \\
\cline { 2 - 9 } & Nat. & IVF & Nat. & IVF & Nat. & IVF & Nat. & IVF \\
\hline N & 278 & 100 & 275 & 101 & 270 & 91 & 278 & 92 \\
Mean & 20.9 & 22.4 & 22.1 & 23.4 & 21 & 22.5 & 20 & 20.6 \\
Median & 22 & 23 & 24 & 24 & 22 & 23 & 21 & 22 \\
Mode & 24 & 26 & 26 & 24 & 22 & 24 & 20 & 22 \\
Std. Deviation & 5 & 4.1 & 5.7 & 4.5 & 5 & 4 & 5.6 & 5.4 \\
Dispersion & 25 & 17.1 & 32.7 & 20.1 & 24.7 & 16.4 & 31.5 & 29.5 \\
\hline
\end{tabular}

Table 7 presents the descriptive statistics for emotional warmth and hostility of the relationship, the composite index of marital relationships, and the results of comparative analysis of the groups. The Mann-Whitney $U$ test demonstrates that all scores of marital relations in our sample are slightly higher in the IVF group than in the natural conception group, which indicates warmer and less hostile relationships.

Table 7

Warmth and hostility of the relationship and composite relationship index (Iowa scale)

\begin{tabular}{lcccccc}
\hline & \multicolumn{2}{c}{ Warmth } & \multicolumn{2}{c}{ Hostility (reversed) } & \multicolumn{2}{c}{ Composite } \\
\cline { 2 - 7 } & Nat. & IVF & Nat. & IVF & Nat. & IVF \\
\hline $\mathrm{N}$ & 265 & 89 & 261 & 88 & 252 & 87 \\
Mean & 27.29 & 29 & 20.9 & 22.25 & 24.1 & 25.65 \\
Median & 29 & 30 & 22 & 23 & 25.5 & 26.5 \\
Mode & 35 & 34.25 & 22 & 25.25 & 26.9 & 20.25 \\
Std. Deviation & 6.4 & 5.175 & 4.75 & 3.72 & 5.3 & 4.21 \\
Dispersion & 41.2 & 26.8 & 22.6 & 13.8 & 28.2 & 17.7 \\
Mann-Whitney U test & \multicolumn{2}{c}{9,990} & \multicolumn{2}{c}{9,766} & \multicolumn{2}{c}{9,149} \\
p & \multicolumn{2}{c}{0.03} & \multicolumn{2}{c}{0.04} & & \multicolumn{2}{c}{0.02} \\
\hline
\end{tabular}

Note. The composite index was calculated as the sum of the two scales, where the scale of hostility was reversed (high scores indicate low hostility).

Table 8 presents correlations between family relations (warmth, hostility, and overall relations) and psychological states (depression, anxiety, inward and outward irritability), separately for the IVF and natural pregnancy groups, and 
Table 8

Relationship between negative psychological states of spouses and marital relations

\begin{tabular}{|c|c|c|c|c|c|c|}
\hline $\begin{array}{c}\text { Pairs of } \\
\text { variables }(r)\end{array}$ & $\begin{array}{c}\text { Women } \\
\text { Nat. } \\
\mathrm{N}=247-263\end{array}$ & $\begin{array}{c}\text { Women } \\
\text { IVF } \\
\mathrm{N}=84-86\end{array}$ & $\begin{array}{l}Z \text { (p value) } \\
\text { Nat vs IVF } \\
\text { Women }\end{array}$ & $\begin{array}{c}\begin{array}{c}\text { Men } \\
\text { Nat }\end{array} \\
\mathrm{N}=246-263\end{array}$ & $\begin{array}{c}\text { Men } \\
\text { IVF } \\
\mathrm{N}=\mathbf{8 5 - 8 9}\end{array}$ & $\begin{array}{c}\mathrm{Z} \text { (p value) } \\
\text { Nat vs IVF } \\
\quad \text { Men }\end{array}$ \\
\hline $\begin{array}{l}\text { Warmth- } \\
\text { Depression }\end{array}$ & $-0.18^{* *}$ & $-0.30^{* \star}$ & $\begin{array}{c}1.0 \\
(p=0.16)\end{array}$ & $-0.26^{* *}$ & -0.14 & $\begin{array}{c}-0.97 \\
(\mathrm{p}=0.17)\end{array}$ \\
\hline $\begin{array}{l}\text { Warmth- } \\
\text { Outward } \\
\text { Irritability }\end{array}$ & $-0.20^{\star *}$ & $-0.30^{* *}$ & $\begin{array}{c}0.79 \\
(p=0.21)\end{array}$ & $-0.24^{* *}$ & -0.21 & $\begin{array}{c}-0.31 \\
(\mathrm{p}=0.38)\end{array}$ \\
\hline $\begin{array}{l}\text { Warmth- } \\
\text { Inward } \\
\text { Irritability }\end{array}$ & $-0.17^{* *}$ & $-0.25^{*}$ & $\begin{array}{c}0.65 \\
(p=0.26)\end{array}$ & $-0.18^{* *}$ & -0.17 & $\begin{array}{c}-0.10 \\
(\mathrm{p}=0.46)\end{array}$ \\
\hline $\begin{array}{l}\text { Warmth- } \\
\text { Anxiety }\end{array}$ & $-0.22^{* *}$ & -0.08 & $\begin{array}{c}-1.07 \\
(\mathrm{p}=0.14)\end{array}$ & $-0.19^{* *}$ & -0.17 & $\begin{array}{c}-0.16 \\
(p=0.44)\end{array}$ \\
\hline $\begin{array}{l}\text { Hostility- } \\
\text { Depression }\end{array}$ & $-0.24^{* *}$ & $-0.32^{* *}$ & $\begin{array}{c}0.68 \\
(p=0.25)\end{array}$ & $-0.22^{* *}$ & $-0.27^{*}$ & $\begin{array}{c}0.45 \\
(p=0.33)\end{array}$ \\
\hline $\begin{array}{l}\text { Hostility- } \\
\text { Outward } \\
\text { Irritability }\end{array}$ & $-0.35^{* *}$ & $-0.42^{* *}$ & $\begin{array}{c}0.57 \\
(p=0.28)\end{array}$ & $-0.31^{* *}$ & $-0.22^{*}$ & $\begin{array}{c}-0.79 \\
(\mathrm{p}=0.21)\end{array}$ \\
\hline $\begin{array}{l}\text { Hostility- } \\
\text { Inward } \\
\text { Irritability }\end{array}$ & $-0.30^{* *}$ & -0.20 & $\begin{array}{c}-0.86 \\
(\mathrm{p}=0.19)\end{array}$ & $-0.25^{* *}$ & -0.16 & $\begin{array}{c}-0.73 \\
(\mathrm{p}=0.23)\end{array}$ \\
\hline $\begin{array}{l}\text { Hostility- } \\
\text { Anxiety }\end{array}$ & $-0.29^{* *}$ & -0.13 & $\begin{array}{c}-1.39 \\
(\mathrm{p}=0.08)\end{array}$ & $-0.21^{* *}$ & -0.09 & $\begin{array}{c}-0.96 \\
(\mathrm{p}=0.17)\end{array}$ \\
\hline $\begin{array}{l}\text { Relations- } \\
\text { Depression }\end{array}$ & $-0.35^{* *}$ & $-0.35^{* *}$ & $\begin{array}{c}1.23 \\
(\mathrm{p}=0.11)\end{array}$ & $-0.26^{* *}$ & $-.22^{*}$ & $\begin{array}{c}-0.36 \\
(p=0.36)\end{array}$ \\
\hline $\begin{array}{l}\text { Relations- } \\
\text { Outward } \\
\text { Irritability }\end{array}$ & $-0.30^{* *}$ & $-0.40^{* \star}$ & $\begin{array}{c}0.93 \\
(p=0.18)\end{array}$ & $-0.30^{* *}$ & $-.23^{*}$ & $\begin{array}{c}-0.56 \\
(p=0.29)\end{array}$ \\
\hline $\begin{array}{l}\text { Relations- } \\
\text { Inward } \\
\text { Irritability }\end{array}$ & $-0.25^{\star *}$ & $-0.25^{*}$ & $0(\mathrm{p}=0.5)$ & $-0.25^{* *}$ & -0.16 & $\begin{array}{c}-0.43 \\
(\mathrm{p}=0.33)\end{array}$ \\
\hline $\begin{array}{l}\text { Relations- } \\
\text { Anxiety }\end{array}$ & $-0.27^{* \star}$ & -0.12 & $\begin{array}{c}-1.21 \\
(p=0.11)\end{array}$ & $-0.27^{\star *}$ & -0.15 & $\begin{array}{c}-0.44 \\
(\mathrm{p}=0.33)\end{array}$ \\
\hline
\end{tabular}

Note. ${ }^{*}$ Correlation significant at $p=0.01$. ${ }^{\star}$ Correlation significant at $p=0.05 . Z=$ Fisher $Z$, comparison between IVF and natural pregnancy groups. The sign of $Z$ can be ignored, with significance level indicating whether the stronger correlation (positive or negative) is significantly stronger. 
separately for men and women. The results show that family relations modestly correlate negatively with all psychological states, with lower warmth and greater hostility associated with more negative affect. Several correlations in the IVF groups (both men and women) did not reach significance; however, the correlation coefficients, made separately for men and women, showed that the correlations for IVF vs. natural pregnancy groups did not differ significantly (see Fisher Z in Table 8). Since the Ns in the IVF groups were smaller, it is likely that the sample was underpowered to detect some of the weak associations.

\section{Correlations Between Negative Psychological States of Spouses}

Spearman's rank correlation was used to assess whether the psychological states of spouses were correlated. In the natural conception group, depression experienced by men positively correlated with women's depression $(r=0.30$, $\mathrm{p}=0.00)$, as well as with women's outward irritability $(\mathrm{r}=0.17, \mathrm{p}=0.00)$ and anxiety $(r=0.14, p=0.02)$. Men's depression also modestly correlated with their spouse's stress level in the second trimester $(\mathrm{r}=-0.16, \mathrm{p}=0.01)$ and third trimester $(\mathrm{r}=-0.15, \mathrm{p}=0.01)$; the negative sign of the correlation is due to low scores corresponding to high stress. Men's outward irritability positively correlated with all women's negative psychological states $(r=0.17-0.19 ; \mathrm{p}<0.01)$, with the exception of inward irritability. Men's inward irritability positively correlated with their partners' inward irritability $(\mathrm{r}=0.18 ; \mathrm{p}=0.00)$, outward irritability $(\mathrm{r}=0.21 ; \mathrm{p}=0.00)$, and anxiety $(\mathrm{r}=0.12 ; \mathrm{p}=0.04)$. Men's anxiety positively correlated with all negative psychological states of the pregnant women and their stress level in the second and third trimester. The strongest correlations were observed between depression in both partners $(r=0.30 ; p=0.00)$, between men's anxiety and women's depression $(\mathrm{r}=0.26 ; \mathrm{p}=0.00)$, and between men's and women's anxiety $(r=0.24 ; \mathrm{p}=0.00)$.

In the couples with induced pregnancy, fewer significant correlations were observed, likely due to an underpowered sample. Significant positive correlations were observed between both partners' outward irritability $(r=0.23 ; p=0.03)$, men's inward irritability and women's outward $(\mathrm{r}=0.25 ; \mathrm{p}=0.02)$ and inward $(\mathrm{r}=0.25$; $\mathrm{p}=0.02)$ irritability.

\section{Correlations Between Partner-Reported and Perceived Partner's Warmth and Hostility}

Analysis revealed moderate significant correlations between partner-reported and perceived warmth and hostility; as well as between partners' actual warmth and hostility in both groups (see Tables 9 and 10). Correlations were also observed between men's and women's perceived warmth and actual hostility and between the warmth of one partner and the hostility of the other. 
Table 9

Correlations between partner-reported and perceived warmth/hostility in the natural conception group

\begin{tabular}{|c|c|c|c|c|c|}
\hline & & $\begin{array}{l}\text { Woman's } \\
\text { warmth } \\
\text { towards man }\end{array}$ & $\begin{array}{l}\text { Woman's } \\
\text { hostility } \\
\text { towards man }\end{array}$ & $\begin{array}{l}\text { Woman's } \\
\text { perceived warmth } \\
\text { of her partner }\end{array}$ & $\begin{array}{c}\text { Woman's } \\
\text { perceived hostility } \\
\text { of her partner }\end{array}$ \\
\hline \multirow{3}{*}{$\begin{array}{l}\text { Man's warmth } \\
\text { towards woman }\end{array}$} & $\mathrm{R}$ & $0.47^{* *}$ & $0.36^{* *}$ & $0.58^{* *}$ & $0.41^{* *}$ \\
\hline & $\mathrm{p}$ & 0.00 & 0.00 & 0.00 & 0.00 \\
\hline & $\mathrm{N}$ & 271 & 272 & 268 & 269 \\
\hline \multirow{3}{*}{$\begin{array}{l}\text { Man's hostility } \\
\text { towards woman }\end{array}$} & $\mathrm{R}$ & $0.44^{* *}$ & $0.58^{* *}$ & $0.50^{* *}$ & $0.66^{* *}$ \\
\hline & $\mathrm{p}$ & 0.00 & 0.00 & 0.00 & 0.00 \\
\hline & $\mathrm{N}$ & 264 & 266 & 261 & 263 \\
\hline \multirow{3}{*}{$\begin{array}{l}\text { Man's perceived } \\
\text { warmth of } \\
\text { partner }\end{array}$} & $\mathrm{R}$ & $0.58^{* *}$ & $0.51^{* *}$ & $0.60^{* *}$ & $0.49^{* *}$ \\
\hline & $\mathrm{p}$ & 0.00 & 0.00 & 0.00 & 0.00 \\
\hline & $\mathrm{N}$ & 274 & 275 & 271 & 272 \\
\hline \multirow{3}{*}{$\begin{array}{l}\text { Man's perceived } \\
\text { hostility of } \\
\text { partner }\end{array}$} & $\mathrm{R}$ & $0.42^{* *}$ & $0.68^{* *}$ & $0.45^{* *}$ & $0.57^{* *}$ \\
\hline & $\mathrm{p}$ & 0.00 & 0.00 & 0.00 & 0.00 \\
\hline & $\mathrm{N}$ & 272 & 274 & 269 & 271 \\
\hline
\end{tabular}

Note. ${ }^{*}$ Correlation significant at $p=0.00$. Positive correlations between actual/perceived warmth and hostility indicate negative associations (hostility scores were reversed).

Table 10

Correlations between partner-reported and perceived warmth/hostility in the IVF group

\begin{tabular}{lccccc}
\hline & & $\begin{array}{c}\text { Woman's } \\
\text { warmth } \\
\text { towards man }\end{array}$ & $\begin{array}{c}\text { Woman's } \\
\text { hostility } \\
\text { towards man }\end{array}$ & $\begin{array}{c}\text { Woman's } \\
\text { perceived warmth } \\
\text { of her partner }\end{array}$ & $\begin{array}{c}\text { Woman's } \\
\text { perceived hostility } \\
\text { of her partner }\end{array}$ \\
\hline Man's warmth & $\mathrm{R}$ & $0.45^{* *}$ & $0.29^{* *}$ & $0.60^{* *}$ & $0.48^{* *}$ \\
towards woman & $\mathrm{P}$ & 0.00 & 0.01 & 0.00 & 0.00 \\
& $\mathrm{~N}$ & 90 & 89 & 89 & 90 \\
\hline Man's hostility & $\mathrm{R}$ & $0.40^{* *}$ & $0.34^{* *}$ & $0.53^{* *}$ & $0.49^{* *}$ \\
towards woman & $\mathrm{P}$ & 0.00 & 0.00 & 0.00 & 0.00 \\
\hline Man's perceived & $\mathrm{N}$ & 89 & 88 & 88 & 89 \\
warmth of & $\mathrm{P}$ & $0.45^{* *}$ & $0.41^{* *}$ & $0.59^{* *}$ & $0.54^{* *}$ \\
partner & $\mathrm{N}$ & 90 & 0.00 & 0.00 & 0.00 \\
\hline Man's perceived & $\mathrm{R}$ & $0.43^{* *}$ & $0.54^{* *}$ & $0.56^{* *}$ & 90 \\
hostility of & $\mathrm{P}$ & 0.00 & 0.00 & 0.00 & $0.47^{* *}$ \\
partner & $\mathrm{N}$ & 90 & 89 & 89 & 0.00 \\
\hline
\end{tabular}

Note. ${ }^{*}$ Correlation significant at $p \leq 0.01$. Positive correlations between actual/perceived warmth and hostility indicate negative associations (hostility scores were reversed). 


\section{Discussion}

The first hypothesis of the study was not supported. Families with induced pregnancy did not experience greater stress and negative affect than families with natural pregnancies. The results showed relatively low stress for the majority of women, both with natural and induced pregnancy. Nevertheless, a small proportion of women in both groups experienced elevated levels of stress. There was some indication that stress levels were uneven across the trimesters, with a greater proportion of women in the IVF group showing elevated stress in the second trimester. The differences were not statistically significant, but the pattern of these results was consistent with previous literature on the prevalence of stress in infertile women (Hashemieh, Neisani Samani, \& Taghinejad, 2013). Elevated stress in this group can be associated with complications during pregnancy or with women's fears based on information about the possible difficulties and risks of pregnancy (Crespo \& Bestard, 2016).

Most women in both groups had scores in the normal range for depression, irritability, and anxiety. Nevertheless, in both groups a small proportion of women had elevated levels of these negative psychological states. Women with a natural pregnancy had greater outward irritability than women with an induced pregnancy. This may be due to the "desired baby" effect, which allows women who conceived with IVF to be more resilient to hormone-related irritability and emotional instability experienced during pregnancy. Previous research suggested that $100 \%$ of women undergoing IVF treatment view their pregnancy as desirable (and long awaited), whereas this proportion is smaller in women with a natural pregnancy (Naku et al., 2016).

Most men in both groups also had scores in the normal range for negative psychological states during their partners' pregnancy; however, there was a small proportion of participants with high levels of depression, irritability, and anxiety in both groups, which is in line with previous research (Darwin et al., 2017).

The second hypothesis of the study was supported. Experience of more negative psychological states (depression, anxiety, irritability) was associated with greater stress experienced by women during pregnancy. Modest to moderate correlations were observed between all negative psychological states and stress level in all trimesters of pregnancy in both groups. The results also indicated that the association between stress and negative affect may be particularly strong in the third trimester. The findings of associations between stress and negative affect are in line with research that found associations between distress and depression and other negative states (McLaughlin \& Hatzenbuehler, 2009; Schneiderman, Ironson, \& Siegel, 2005). Irritability and anxiety can be accompanied by an increase in stress during pregnancy; in turn, stress can contribute to irritability, anxiety, and depression. These findings highlight the importance of providing support and advice to women during the pregnancy on how to deal with negative emotional states.

In the group of women with IVF, outward irritability was accompanied by an increase in stress only during the first and second trimesters; in the second and third trimesters, stress was correlated with anxiety. Such dynamics in the IVF group can be explained by the fact that in the last trimesters of pregnancy, the focus of the spouses in the IVF group shifts to worrying about maintaining a healthy preg- 
nancy, in light of the known elevated risk of miscarriage after IVF. Future research is needed to replicate the dynamics observed in this study. Comparison of the correlation coefficients showed that in the first trimester, correlation between stress and inward irritability was greater in the natural pregnancy group than in the IVF group. In the second trimester, correlation between stress and depression was significantly greater in the group of women with an induced pregnancy. In the third trimester, stress was correlated more strongly with anxiety, outward irritability, and inward irritability in the natural pregnancy group than in the IVF group.

The third hypothesis of the study was also supported. Modest to moderate associations between the relationship of spouses and their psychological states were observed. Comparisons of the correlation coefficients between psychological states and marital relations showed similar correlations in the IVF and natural pregnancy groups, with no significant differences. Lower warmth and greater hostility towards the partner was associated with higher levels of negative affect in both the IVF and natural pregnancy groups. Some associations in the IVF groups did not reach significance, which may be explained by the underpowered sample. These results are consistent with previous research that found associations between spousal relations and psychological states (Figueiredo et al., 2008; Tanner Stapleton et al., 2012).

The fourth hypothesis was also supported. The significant positive modest correlations between psychological states of pregnant women and their partners observed in our study indicate an emotional link and interdependency of some spouses during this time (Figueiredo et al., 2008).

Finally, the fifth hypothesis was also supported. The correlations between partner-reported and perceived warmth and hostility were moderate, ranging from .41 to .68 in the natural conception group, and from 0.41 to 0.6 in the IVF group. These results suggest that most people are overall accurate in their perceptions of their partner's warmth or hostility towards them. However, some tend to misinterpret each other's attitudes or have problems with evaluating or expressing their own attitudes.

\section{Conclusion}

The results suggest that psychological states, stress, and links between psychological states and quality of family relations are similar in families with IVF and natural pregnancies. The levels of negative states were relatively low in both groups. Higher stress was associated with worse emotional states of women during all trimesters of pregnancy. A moderate correlation was observed between spouse-reported warmth/hostility and perceived warmth/hostility. Negative psychological states were modestly related to the quality of family relations.

\section{Limitations}

The present study was based on an opportunistic sample, recruiting women through family-planning clinics; therefore, the participants in the two groups were not specifically matched on any socio-demographic parameters. However, all families came from four clinics in the same general area of Russia, and were therefore comparable. The sample is part of an ongoing longitudinal study, which is con- 
tinuously growing. At the time of the current data analyses, the groups remained relatively small, and unequal in size, which limits the statistical power to find weak associations. However, the results point to overall similarities between the groups. Further longitudinal research is needed to explore the direction of causal links between psychological states of spouses, and between their psychological states and the quality of family relations.

\section{Acknowledgment}

This research was supported by "The Tomsk State University Competitiveness Improvement Program" grant (No. 8.1.11.2018).

\section{References}

Choi, H. \& Marks, N.F. (2008). Marital conflict, depressive symptoms, and functional impairment. Journal of Marriage and the Family, 70(2), 377-390. https://doi.org/10.1111/j.17413737.2008.00488.x

Crespo, E., \& Bestard, J. (2016). Psychosocial needs of women and their partners after successful assisted reproduction treatment in Barcelona. Reproductive Biomedicine \& Society Online, 3, 90-99. https://doi.org/10.1016/j.rbms.2017.04.001

Darwin, Z., Galdas, P., Hinchliff, S., Littlewood, E., McMillan, D., \& McGowan, L. (2017). Fathers' views and experiences of their own mental health during pregnancy and the first postnatal year: A qualitative interview study of men participating in the UK Born and Bred in Yorkshire (BaBY) cohort. BMC Pregnancy and Childbirth, 17, 45. https://doi.org/10.1186/ s12884-017-1229-4

Du Rocher Schudlich, T. D., Papp, L. M., \& Cummings, E. M. (2011). Relations between spouses' depressive symptoms and marital conflict: A longitudinal investigation of the role of conflict resolution styles. Journal of Family Psychology, 25(4), 531-540. https://doi.org/10.1037/ a0024216

Ebbesen, S.M.S, Zachariae, R., Mehlsen, M.Y., Thomsen, D., Højgaard, A., Ottosen, L., Petersen, T., \& Ingerslev, H.J. (2009). Stressful life events are associated with a poor in vitro fertilization (IVF) outcome: A prospective study. Hum Reprod., 24, 2173-2182. https://doi. org/10.1093/humrep/dep185

Fadeeva, N.I., Vostrikov, V.V., \& Garganeeva, A.E. (2011). Emotsional'noe sostoianie i sotsial'nye osobennosti patsientok v rezul'tativnykh i nerezul'tativnykh tsiklakh ekstrakorporal'nogo oplodotvoreniia [Emotional state and social characteristics of patients with successful and unsuccessful IVF cycles. Nevrologicheskii vestnik [Journal of Neurology], 2, 32-36. Retrieved from http://www.fesmu.ru/elib/Article.aspx?id=241453.

Faria, D. E. P., Grieco, S. C., \& Barros, S. M. O. (2012). The effects of infertility on the spouses' relationship. Revista da Escola de Enfermagem da USP, 46(4), 794-801. https://doi. org/10.1590/S0080-62342012000400002

Feklicheva, I.V., Chipeeva, N.A., Voronina, I.D., Soldatova, E.L., Maslennikova, E.P., Shabalovskaya, M. ., Agarkova, L.A., Malykh, S.B., \& Kovas, Yu.V. (2017). Vzaimosviaz' mezhdu otnosheniem $\mathrm{k}$ budushemu rebënku i otnosheniiami mezhdu roditel'iami i sem'iakh so spontannoi i indutsirovannoi bremennost'iu [Relationship between the attitude to an unborn child and the relations between parents in families with spontaneous and induced pregnancy]. Akusherstvo i ginekologiia [Obstetrics and Gynecology], 10, 78-83. https://doi. org/10.18565/aig.2017.10.78-83 
Figueiredo, B., Field, T., Diego, M., Hernandez Reif, M., Deeds, O., \& Ascencio, A. (2008). Partner relationships during the transition to parenthood. Journal of Reproductive and Infant Psychology, 26(2), 99-107. https://doi.org/10.1080/02646830701873057

Filippova, G.G. (2009). Psikhologicheskaia adaptatsiia k beremennosti i roditel'stvu v supruzheskikh parakh $\mathrm{s}$ besplodiem i nevynashivaniem $\mathrm{v}$ amneze [Psychological adaptation to pregnancy and parenthood in married couples with infertility and miscarriage in anamnesis]. Perinatal'naia psikhologiia i psikhologiia roditel'stva [Perinatal Psychology and Psychology of Parenthood], 4, 102-107.

Frederiksen, Y., Farver-Vestergaard, I., Skovgård, N.G., Ingerslev, H.J., \& Zachariae, R. (2015). Efficacy of psychosocial interventions for psychological and pregnancy outcomes in infertile women and men: A systematic review and meta-analysis. BMJ Open, 5(1), e006592. https://doi.org/10.1136/bmjopen-2014-006592

Galhardo, A., Cunha, M., \& Pinto-Gouveia, J. (2011). Psychological aspects in couples with infertility. Sexologies, 20(4), 224-228. https://doi.org/10.1016/j.sexol.2011.08.005

Gourounti, K., Anagnostopoulos, F., Potamianos, G., Lykeridou, K., Schmidt, L., \& Vaslamatzis, G. (2012). Perception of control, coping and psychological stress of infertile women undergoing IVF. Reprod Biomed Online, 24(6), 670-679. https://doi.org/10.1016/j.rbmo.2012.03.002

Greil, A.L., Shreffler, K.M., Schmidt, L. \& McQuillan, J. (2011). Variation in distress among women with infertility: Evidence from a population-based sample. Human Reproduction, 26(8), 2101-2112. https://doi.org/10.1093/humrep/der148

Greil, A.L., Slauson-Blevins, K., \& McQuillan, J. (2010). The experience of infertility: A review of recent literature. Sociology of Health \& Illness, 32(1), 140-162. https://doi.org/10.1111/ j.1467-9566.2009.01213.x

Haimovici, F., Anderson, J.L., Bates, G.W., Racowsky, C., Ginsburg, E.S., Simovici, D., \& Fichorova, R.N. (2018). Stress, anxiety, and depression of both partners in infertile couples are associated with cytokine levels and adverse IVF outcome. Am J Reprod Immunol, 79 (4), e12832. https://doi.org/10.1111/aji.12832

Hashemieh, C., Neisani Samani, L., \& Taghinejad, H. (2013). Assessment of anxiety in pregnancy following Assisted Reproductive Technology (ART) and associated infertility factors in women commencing treatment. Iranian Red Crescent Medical Journal, 15(12), e14465. https://doi.org/10.5812/ircmj.14465

Hjelmsted, A., Widström, A.M., Wramsby, H., Matthiesen, A.S., \& Collins A. (2003). Personality factors and emotional responses to pregnancy among IVF couples in early pregnancy: A comparative study. ActaObstetGynecolScand, 82(2), 152-161.

Hjelmstedt, A., Widström, A.M., Wramsby, H., \& Collins, A. (2003). Patterns of emotional responses to pregnancy, experience of pregnancy and attitudes to parenthood among IVF couples: A longitudinal study. Journal of Psychosomatic Obstetrics \& Gynecology, 24(3), 153-162, https://doi.org/10.3109/01674820309039669

Hynes, G.J., Callan, V.J., Terry, D.J., \& Gallois, C. (2011). The psychological well-being of infertile women after a failed IVF attempt: The effects of coping. Br. J. Med. Psychol, 65(3), 269-278.

Klemetti, R., Raitanen, J., Sihvo, S., Saarni, S., \& Koponen, P. (2010). Infertility, mental disorders and well-being-a nationwide survey. Acta Obstetricia et Gynecologica Scandinavica, 89, 677-682. https://doi.org/10.3109/00016341003623746

Klock, S.C. \& Greenfeld, D.A. (2000). Psychological status of in vitro fertilization patients during pregnancy: A longitudinal study. Fertility and Sterility, 73(6), 1159-1164. https://doi. org/10.1016/S0015-0282(00)00530-6

Kouros, C.D. \& Cummings, E.M. (2011). Transactional relations between marital functioning and depressive symptoms. American Journal of Orthopsychiatry, 81, 128-138. 
Kouros, C.D., Papp, L.M., \& Cummings, E.M. (2008). Interrelations and moderators of longitudinal links between marital satisfaction and depressive symptoms among couples in established relationships. Journal of Family Psychology, 22(5), 667-677. https://doi. org/10.1037/0893-3200.22.5.667

Lin, Y.H. \& Chueh, K.H. (2016). Somatic symptoms, sleep disturbance and psychological distress among women undergoing oocyte pick-up and in vitro fertilisation-embryo transfer. $J$ ClinNurs., 25, 11-12, 1748-1756. https://doi.org/10.1111/jocn.13194

Maroufizadeh, S., Karimi, E., Vesali, S., \& Omani Samani, R. (2015). Anxiety and depression after failure of assisted reproductive treatment among patients experiencing infertility. International Journal of Gynecology \& Obstetrics, 130, 253-256. https://doi.org/10.1016/j. ijgo.2015.03.044

Massey, A.J., Campbell, B.K., Raine-Fenning, N., Pincott-Allen, C., Perry, J., \& Vedhara, K. (2016). Relationship between hair and salivary cortisol and pregnancy in women undergoing IVF. Psychoneuroendocrinology, 74, 397-405. https://doi.org/10.1016/j.psyneuen.2016.08.027

McLaughlin, K.A., \& Hatzenbuehler, M.L. (2009). Stressful life events, anxiety sensitivity, and internalizing symptoms in adolescents. Journal of Abnormal Psychology, 118(3), 659-669. https://doi.org/10.1037/a0016499

Melby, J., Conger, R., Book, R., Rueter, M., Lucy, L., Repinski, D., \& Scaramella, L. (1998). The Iowa Family Interaction Rating Scales (5th ed.). Unpublished document, Iowa State University, Institute for Social and Behavioral Research.

Naku, E.A., Bohan, T.G., Ulyanich, A.L., Shabalovskaya, M.V., Tosto, M., Terehina, O.V., \& Kovas, Yu.V. (2016). Psikhologicheskie kharakteristii zhenshchin, prokhodiashchikh lechenie po programme EKO [Psychological characteristics of women undergoing IVF treatment]. Voprosy ginekologii, akusherstva i perinatologii [Issues of Gynecology, Obstetrics and Perinatology], 15(6), 23-30. https://doi.org/10.20953/1726-1678-2016-6-23-30

Naku, E.F., Kovas, Yu.V., Bohan, T.G., Terehina, O.V., \& Vidyakina, T.A. (2017). Faktory negativnykh psikhoemotsional'nykh sostoianii zhenshchin, prokholdiashchikh lechenie besplodiia po programme EKO [Factors of negative psycho-emotional states among women undergoing IVF treatment]. Sibirskii psikhologicheskii zhurnal [Siberian Psychological Journal], 63, 119-136. https://doi.org/10.17223/17267080/63/9

Pasch, L.A., Holley, S.R., Bleil, M. E., Shehab, D., Katz, P.P., \& Adler, N.E. (2016). Addressing the needs of fertility treatment patients and their partners: Are they informed of and do they receive mental health services? Fertility and Sterility, 106(1), 209-215.e2. https://doi. org/10.1016/j.fertnstert.2016.03.006

Pellerone, M. \& Miccichè, S. (2014). Prenatal attachment and anxiety: Women who decide to try in vitro fertilization and women who procreate naturally. Psychol. Res., 4(6), 419-427. https://doi.org/10.17265/2159-5542/2014.06.002

Petrova, N.N., Podolhov, E. N., Gzgzyan, A.M., \& Ngauri, D.A. (2013). Psikhicheskie rasstroistva i lichnostno-psikhologicheskie osobennosti u zhenshchin s besplodiem pri lechenii EKO [Mental disorders and personality-psychological features in women with infertility in treatment with IVF]. Obzor psikhiatrii i meditsinskoi psikhologii [Review of Psychiatry and Medical Psychology], 2, 42-49.

Purewal, S., Chapman, S., \& Van Den Akker, O. (2017). A systematic review and meta-analysis of psychological predictors of successful assisted reproductive technologies. BMC Research Notes, 10(711). https://doi.org/10.1186/s13104-017-3049-z

Rice, F., Harold, G.T., Boivin, J., van den Bree, M., Hay, D.F., \& Thapar, A. (2010). The links between prenatal stress and offspring development and psychopathology: Disentangling environmental and inherited influences. Psychological Medicine, 40(2), 335-345. https://doi. org/10.1017/S0033291709005911 
Sbaragli, C., Morgante, G., Goracci, A., Hofkens,T., DeLeo, V., \& Castrogiovanni, P. (2008). Infertility and psychiatric morbidity. Fertility and Sterility, 90, 2107-2111. https://oi. org/10.1016/j.fertnstert.2007.10.045

Schneiderman, N., Ironson, G., \& Siegel, S. D. (2005). Stress and health: Psychological, behavioral, and biological determinants. Annual Review of Clinical Psychology, 1, 607-628. https:// doi.org/10.1146/annurev.clinpsy.1.102803.144141

Seok Kee, B., Jung, B.J., \& Lee, S.H.J. (2000). A study on psychological strain in IVF patients. Assist Reprod Genet, 17(8), 445-448. https://doi.org/10.1023/A:1009417302758

Snaith, R.P., Constantopoulos, A.A., Jardine, M.Y., \& McGuffin, P. (1978). A clinical scale for the self-assessment of irritability. British Journal of Psychiatry, 132, 163-171. https://doi. org/10.1192/bjp.132.2.164

Tanner Stapleton, L.R., Schetter, C.D., Westling, E., Rini, C., Glynn, L.M., Hobel, C.J., \& Sandman, C.A. (2012). Perceived partner support in pregnancy predicts lower maternal and infant distress. Journal of Family Psychology, 26(3), 453-463. https://doi.org/10.1037/a0028332

Voronina, I.D., Bohan, T.G., Terehina, O.V., Malykh, S.B., \& Kovas, Y. (2016). Demograficheskie pokazateli, obraz zhiznii i zdorov'e v sem'iakh s estestvennoi i indutsirovannoi bremennost'iu v Rossii i Velikobritanii [Demographics, lifestyle and health in families with natural and induced pregnancy in Russia and the UK]. Teoreticheskaia i eksperimental'naia psikhologiia [Theoretical and Experimental Psychology], 9(4), 63-76.

Vujeva, H.M. \& Furman, W. (2011). Depressive symptoms and romantic relationship qualities from adolescence through emerging adulthood: A longitudinal examination of influences. Journal of Clinical Child and Adolescent Psychology, 40, 123-135. https://doi.org/10.1080/1 5374416.2011 .533414

Wichman, C.L., Ehlers, S.L., Wichman, S.E., Weaver, A.L., \& Coddington, C. (2011). Comparison of multiple psychological distress measures between men and women preparing for in vitro fertilization. Fertility and Sterility, 95, 717-721. https://doi.org/10.1016/j.fertnstert.2010.09.043

Williams, K.E., Marsh, W.K., \& Rasgon, N.L. (2007). Mood disorders and fertility in women: A critical review of the literature and implications for future research. Human Reproduction Update, 13(6), 607-616. https://doi.org/10.1093/humupd/dmm019

Zaharova, E.I. \& Yakupova, V.A. (2015). Vnutrenniaia materinskaia pozitsiia zhenshchin, bremennost' kotorykh nastupila s pomoshch'iu EKO [Internal maternal position of women who became pregnant using IVF]. Natsional'nyi psikhologicheskii zhurnal [National Psychological Journal], 1(17), 96-104. https://doi.org/10.11621/npj.2015.0111 